\title{
Interactions of the Russian State with Emigrant Communities
}

\author{
Varfolomey A. Bazanov* \\ Moscow State Institute of International Relations \\ Ludwig-Maximilians-University of Munich (Germany) \\ 1 Geschwister-Scholl-Platz, München, 80539, Deutschland
}

Received 22.04.2016, received in revised form 23.07.2016, accepted 22.09.2016

The article compares on the basis of a qualitative case study in Germany the formation and comparison of migrants groups' settings towards the state and to state holidays.

Based on the analysis performed 75 thematically structured interviews the article compares the resettlement features of the two migrants groups, their behaviour and their attitude to the state authorities and state events. On the one hand, the representatives of the "Russian abroad" have distanced themselves for a long time from the state, which was located on the territory of origin, whereas the representatives of the "new wave" associates themselves with (post) soviet cultural system. As a result one can see in the "new wave" migrants a combination of Soviet and Russian identities. On the other hand, the state itself is not perceived by the "Russian world" in a hostile way. The "new wave" migrants often just transferred their cautious attitude to the origin state to the local state. For example the police for the fourth wave migrant associated more with the threat, with negative feelings, while for the "old migration" the policeman is uniquely defender.

Common holiday promotes cultural practices and standardized behaviours, but under conditions of existence of migrants with different interpretations of historical events it is difficult to talk about the presence of general holidays. The study tested also the differences in the holiday's symbolic regulation. Interpretation of historical events is heir more an area of disagreement. One of the most remarkable in recent years the symbol of the victory Ribbon of St. George, for example, is not perceived so unequivocally positive, as among "new migrants".

This description confirms the thesis about the existence of the two cultural groups within the Russianspeaking space. The selection of specific cultural groups can increase the efficiency of the work with compatriots abroad.

Keywords: migrants, cultural space, symbol, state holiday, "Russian abroad", soft power.

DOI: 10.17516/1997-1370-2016-9-10-2328-2341.

Research area: sociology.

Consistent and systematic work on the optimization of public image abroad is one of the most important aspects of the policy of "soft power." Such work should be regarded as an important component of information support of the foreign policy activities of the Russian state. Ignoring of this area can lead to a loss of international positions, an emergence of obstacles

(C) Siberian Federal University. All rights reserved

* Corresponding author E-mail address: v.a.bazanov@gmail.com 
in advancing of the interests of Russian business abroad. Positive perception of Russia in the world may greatly facilitate the success of social and economic reforms. A special place in the complex of measures for improvement of the country's image is the work with the departed migrants who, after Alexander Neklessa, start to form an entirely new kind of typology of Russia social space [17, p.38]. This space largely influences the perception of Russia abroad. It should be noted, that in recent years, Russian authorities are trying to use the migrants coming into the country, to improve the demographic situation. And migrants leaving the country are used as a resource of impact and a tool for improving of the political image. One of the problems mentioned in the concept of Russia's foreign policy involves the expenditure of resources, to "promote the consolidation of the compatriots" organizations in order to their more efficient provision of rights in countries of their residence, as well as to preserve ethnic and cultural identity of the Russian diaspora and its connection with the historical homeland ..." [13, p.6]. We can observe the direction of application of state's efforts and resources. So, the fund "Russian world"establishes its offices worldwide. On the $5^{\text {th }}$ of March 1999 it was adopted the Act on the state policy on compatriots abroad [8]. The Ministry of Foreign Affairs website contains a link to information for "compatriots", special government programs are held. On the 22nd of June, the President of Russia signed a Decree No. 637, by which he approved the State Program of Assistance to the voluntary migration of compatriots living abroad into the Russian Federation [7]. Since 2006, the work with compatriots is coordinated by the Government Commission on the Affairs of Compatriots Abroad headed by the Minister of Foreign Affairs of Russia Sergey Lavrov. The Councils for Compatriots' Affairs were set up in 15 regions of Russia [4, p.4]. Ministry of Economic
Development is ready to attract "compatriots" for the "formation of a network (corps) of foreigntrade consultants" [10]. Of course, considering the generality of the migration and the dimensions of diaspora, the measures are rather more overdue, because there are at least 30 million people living outside of Russia, the ones, "who, being outside of the homeland as a result of political upheavals, wars and conflicts, however, believes that his or her destiny is tied to the fate of Russia, who, regardless of nationality, carries Russian culture, is a Russian native speaker and doesn't imagine himself or herself outside of the Russianspeaking space" [12, p.13]. Furthermore, in the absence of clear evidence-based public Diaspora policy, on the one hand, the policy of formation of an attractive Russia's image abroad, and, on the other hand, the strengthening of cultural unity and responsibility of the migrants, the efficiency of expended organizational and financial resources is pretty much low. Meanwhile, the issues of relationship of cultural and historical forms of the migrant groups formation are poorly studied theoretically and are not clarified yet on the one hand, and issues of maintaining of cultural attitude processes and cultural characteristics of migrant groups, on the other. Correspondingly, this work is aimed to the further compensation of the gap in distinguishing of groups of migrants from Russia (USSR). Relevance of this study is thus determined by the lack of knowledge about the structure of the Russian language space, as well as special features of components of its groups.

Political and economic transformation of Eastern Europe at the end of the last century had a major impact on the intensity of Diasporas and migrationflows. Thus, thesephenomena caused the mass migration of Russian-speaking population both into Western Europe and in particular into Germany, which led to a substantial increase of the Russian-speaking population in the region. 
It is known that in Germany there already was a quite noticeable Russian-speaking diaspora that emerged after the Russian events of 1917 and increased after the Second World War. And now the main stream of migrants from the former Soviet Union is directed to Germany [38, p.548]. Already by 2003, "the total number of those who speak Russian in Germany exceeds the population of such states as Denmark, Finland, Norway, Croatia, Slovenia and Slovakia" [6, 36]. The situation in Germany gives us a complete picture of the exoduses of Russia. The methodology of the study is the phenomenological tradition in sociology. Features of the scattering structure of Russians and the nature of interaction with the environment will be presented on the basis of analysis of different migrants groups from the Russian Empire, migrants and their descendants from the Soviet Union and from the countries that emerged after the collapse of the USSR living in the Federal State Bavaria in Germany. There were conducted 75 thematically-structured interviews with representatives of the descendants of the first wave of immigration, with participants and descendants of the second, third and fourth waves of immigration, living in Bavaria. The subject of inquiry which is migrants from CIS countries, is presented for research purposes in two groups. The first group, denoted in this work as "Russian abroad" or "old emigration" is formed by the migrants, who left the country between 1917 and 1945, as well as the descendants of these migrants, who were born already in Germany. Migrants of the later period in this study are denoted as "the modern Russian-speaking space" [24]. or "the new migration". At the same time due to the lack of structures of immigrants before the twentieth century and the historical distance of these outcomes, the chronological framework is limited by twentieth and twenty first centuries. The search of appropriate representatives is executed through observation and "snowball". All data obtained in the study do not reflect all of the properties in the general totality. The concept of “cultural identity" after Jan Assmann's approach [2, p.10] was taken as a starting point of the argument. According to this approach, any (specific) collective identity corresponds to a certain "cultural formation", which it substantiates and, most importantly, reproduces it. Jan Assmann believes that collective identity is constructed and reproduced by the interactions that occur within a cultural sense, which refers to a background of common values, experiences, expectations and interpretations, forming "a symbolic semantic world" or "world view" of a society [3, p.140]. Problems of behaviour in the cultural system are considered as well in connection with the ritual of the holiday, as an institution of reproduction of social relations, thereby holiday acts as a tool of social control [28, p.145]. Basing on the value relation to culture, a human reproduces the relationship between culture and social structures in the process of the holiday organization [29].

\section{$\S 1$. Social and historical factors of Russian-speaking emigrant communities}

Several outcomes are distinguished in the investigation of migration flows from the territory of the former USSR. So, Akhiezer A.C. identified six stages of emigration from Russia [1], three of them relate to the period before 1917, and three stages after that date; indicated periodization generally coincides with the one, proposed by Pushkareva N.L. [26]. In general, for years of prerevolutionary emigration from Russia after V.A. Tishkov's calculations, had left about 4.5 million people, "only less than 500 thousand of them were Russians, Ukrainians and Belarusians" [34, p.29]. From 1917 to 1952 is the period that "covers the subsequent devastation, civil war and rose on their basis totalitarian system" [1]. 
In Pushkareva's periodization this period is divided into two stages, where the second stage is associated with the defectors of the World War II period [26]. Outcome caused by the events of 1917 is different in its nature from previous eras of migration, particularly, it differs by the fact, that in a relatively short period of time the country left according to various calculations from 700 thousand [27] to 3.5 million - 4.0 million [37] people. Moreover, if during the period from 1861 to 1915 "two-thirds of emigrants were heading to the USA, and from among the ones, who left in XX century, $80 \%$ headed to the US" [35], at the above mentioned period, migrants were scattered over the European countries. Over a period of intense migration borders of the USSR began to lose any permeability. The period of closure was followed by a new exodus of migrants over the USSR borders during the Second World War, when 0.5 million [19] - 10.0 million [32] people appeared beyond the Soviet Union, avoiding repatriation to their homeland. Alternation of periods of closure and mass exoduses allows using term "wave" to describe those migration periods. "It's more figurative than a scientific concept" [18, p.502], however, "it became widespread and settled terminologically" [18, p. 502, see also 33, p.19]. Moreover, some researchers [18, 35, 37] start the countdown of exoduses since the migration after 1917. In the period from 1948 to 1990 the ,third wave“ of migration is marked out, when the USSR was left by 0.5 million [18] - 1.1 million [22] people. According to Akhiezer's periodization this stage of emigration continues from 1952 to 1992, during ,the return of other nations on their ethnic territory" [1], which is manifested in the emigration of ethnic minorities - Jews, Greeks, Germans, etc. Dissidents were leaving the country as well, and the change in intensity of their leaving allowed Pushkareva to highlight in this period ,pre-perestroika“ and „perestroika“ stages [26]. After the first of January 1993 when the entry and exit law came into force, adopted by the deputies of the USSR in 1991, according to Pushkareva's and Akhiezer's periodization begins the sixth stage, which continues up today [23]. Liberalization of migration policy during ,perestroika“ has led to a new increase in the number of migrants. This tendency was reinforced by processes caused by the collapse of the Soviet Union; especially because at that stage Russia (its political elites and public opinion) became a ,natural centre of gravity“ [21, p. 134] for groups of migrants from the new independent states on the territory of the Soviet Union, and it was not ready to accept such a large number of migrants [15, p.153]. Migration of the above specified period, ,is increasingly characterized by the features that are typical nowadays for emigration from many countries. It is predetermined not by the political factors as before, but by the economic factors, which force people to move to other countries in search of a higher income, a prestigious job, a different quality of life" [37]. The term wave, apparently, is well founded due to the mass exodus; only for eleven years - „from 1990 to 2000 - about 1.1 million people had left Russia.“ [37]. Studying the migration flows from the territory of the former USSR, the Soviet Union and the Russian Empire, several exoduses are distinguished, and their causes and features of their behaviour differ much. Thereby the "outbursts" of emigration exoduses are quite clearly distinguished by the size and time frameworks, caused by events associated with the establishment, special features of policy and the collapse of the Soviet Union. Such exoduses are often called „waves“ of migration. Such features of the migration exoduses as large-scale participation and limited time framework allow assuming the emergence in European countries of migrant communities from many different cultures. At the same time features of culture of each migrant wave are not always 
identical: the cultural features of migrants of the first and second wave forming „Russian abroad“ [22] ,are not typical for the other categories of compatriots, who form "transnational Russianspeaking space" who take their origin in the third, and subsequently, the fourth outcome of the USSR and the new Russia” [22].

\section{$\S 2$ The perception of state by different groups of migrants}

The first wave of migration is associated with Russian political events of 1917, the Civil War and the first actions of the new government, which closed the state during the notable period of time. The first wave is characterized by the powerful push-out factors. It was often not about the availability of benefits, but about the escape from the physical destruction. From the point of view of society which was left by legal citizens of the Russian Empire, it was the loss of mobile and educated part of the population. People who migrated were of different ages and social classes; for example, a significant part of the Russian intelligentsia left Russia. In most cases it is a question of the bearers of "pre-Soviet" culture of the Russian Empire. At the same time, it may be said that the migrants bore the culture, which had no "impurities" that distinguishes that group from all the subsequent ones [23, p.150, 24, p.57]. An external factor, which secured the directivity to closing of external contact, was the state policy towards the migrants of "Russian Abroad": the state of exodus tried in every way to downplay the significance of this group [11, p.81]. Representatives of the second wave, being in the extreme conditions of political repression at their homeland and external military intrusions mainly into the Third Reich territories, could not return because of the threat for their lives [39]. At the same time, it is interesting to note that even people who was sincerely supporting the Red Army and communism could not come back. It is clear that some were captured, a considerable number of people were forcibly deported to the camps, but there were people voluntary leaving the advancing Soviet troops. Some people, who were migrating, were already socialized in the system of functioning Soviet state. This could be seen first of all in contrast to the first wave of migrants, because only a very small part of them had an experience of foreign trips. Secondly, an important role was played by the peculiarities of functioning of information space: very often, people did not believe the official information, whereas the servants of propertied class still were telling their memories about the foreign trips to Europe. It was also influenced by the stories, told by the ones, who were abroad on business trips. Fallen out of information space of their country, many migrants became critical of the status quo in their country, and therefore, in particular, did not believe any official reports about the behaviour of the Germans on the occupied territories, perceiving this information as an extension of Soviet propaganda. A significant part of migrants of the war period is associated with the activities of the Liberation Movement of Peoples of Russia, which consisted of the Liberation Committee of Peoples of Russia and the Russian Liberation Army, which is better known in our country as "Vlasov movement." Principles and ambitions of participants of this movement are in general formulated in the "Prague Manifesto" of 1944. However, this historical document captures certain cultural differences, caused by special features of development of the country of origin. If the ideological base of the first wave can generally be characterized by the formula "Orthodoxy - Autocracy - Nationality" [5], then now no monarchical aspirations are present anymore. But the idea of the need for change in the state, given the fact that the return by existing system is not possible, brought together representatives of the first and second waves. Russian culture was 
conceived at the same time as a culture based on Russian Orthodoxy. Distrust of Soviet propaganda was accompanied by the fear of being arrested, losing relatives. Such a way, representatives of the "Russian Abroad" for a long time distanced themselves from the state, which was located on the territory of exodus, which is not so typical for the representatives of the "new wave". "Alienation" is exacerbated by the returning of symbols of the Soviet Union in the latter period. In Russia, "the direction was taken to a kind of syncretism - a combination of Soviet and Russian identities: it was kept a well-known to Russians music of the Soviet anthem, but the words were changed. The return of the Red Banner to the Russian Armed Forces is another indicator of symbiosis "[20, p.212]. The specified "symbiosis" is perceived by the representatives of the "old emigration" as a rollback to the totalitarian era. Respondents of the "new wave" had a considerable experience of life in Soviet society, therefore they have a clear vision of the Soviet Union, as well as emotionally charged attitude to the state, which has already collapsed. Despite the fact that the respondents had already arrived from the new states, the former Soviet Union could in many cases continue to be considered as a "country of the outcome." "Existence of stable view of the norms of the former Soviet society, regardless of their assessment, is an important identification marker of the group having a single "path in the past"”. [25, p.150-151]

Migrants of the "New wave" have a cautious attitude towards the state in general and this attitude is often transferred to the state of reception. „The state is perceived generally as a repressive machine, but if one knows its rules, it is possible to achieve the goals. The centres of power are seen as alien and hostile; Government seems an arena of conspiracy, deceit, cynicism, or, at least, stupidity and inefficiency. „To beat the system" by outsmarting authorities and bypassing restrictions, rules, laws, is one of the most common virtues" [31, p.5]. It is interesting to note that in this case, migrants comparing officials in the country of origin and the host country are more positive about the host country. Migrants of „Russian Abroad“ don't have that transfer of the attitude to country of origin onto the public authorities of the host country. State, in which these migrants live, is not perceived as hostile. The attitude to the police is representative in this sense: if the migrant of the fourth wave associates police officers more with the threat, with negative experiences, then for the "old migration“ police officer would be uniquely a defender. Besides, if all the representatives of the „Russian abroad“ have solely citizenship of the host country, though reception of Russian citizenship is a difficult procedure, then representatives of the fourth wave, for various reasons, still often have Russian citizenship. In most cases, the institution of citizenship is considered in both groups as a means of solving everyday problems, such as visa-free travel between the countries. For the representatives of the „old emigration“, presence of passport of the host country or of another state means protection from the policy of the country of origin, which was ,aggressive“ to migrants for a long time. For the fourth wave of migrants being a citizen means access to certain resources. Choice of the citizenship of the host country in this case means the consolidation status, especially when perhaps all the relatives left the country of origin. Sometimes it is defined by the fact that immigrants from the former USSR republics don't feel the need and significant gains from citizenship of the newly formed state, and they don't have rights for Russian citizenship anymore. For migrants of „Russian Abroad“ absence of Russian citizenship could mean independence. It is important to note that for the first group of migrants in most cases the intention to return to the country of origin is not a measure of compliance of expectations. The 
age factor is important here, because to change a way of existence, having lived most of his life in Germany, is a difficult task for an elderly person. New generations of migrants are often willing to move to Russia, and such cases are observed, but they want some protection from Germany then. Most desirable option of work is considered to be the work in the branches of German companies in big Russian cities.

\section{§ 3 Official holidays}

Political holiday defining relationship to the past, legitimizing history and often legitimizing the existing regime is a complex tool of updating of some elements of the existing culture. Historical events can be regarded as an artefact of culture, open to transformation. Political holiday is also connected directly or indirectly with the history. It refers to the historical past, its context, if to perceive history as something that comes from the present and is present [2]. At the same time, holiday is the way of communication, which reflects the social order of society and also recreates its value in a special type of reality [28]. Representatives of the second group in general care and associate themselves with public holidays. Thereby most important holidays are considered to be the holidays of the Soviet era, such as Victory Day, International Women's Day, and the Fatherland's Defender Day. One of the most remarkable in recent years is the symbol of the victory, "Ribbon of St. George" which, for example, was handed out to everyone at the Russian consulate on the May $8^{\text {th }}$. The tape with Russian flag colours has become spread as well, which is more popular among the first group of migrants, and Ribbon of St. George is not perceived so unequivocally positive, as among new migrants. It has been observed that migrants of "Russian Abroad" actively used white-blue-red ribbons in the period of the Soviet Union as well, for example, one of the descendants of migrants had her baptismal cross on a ribbon-tricolor. St. George Ribbon colours are actively used in connection with Soviet symbols on one hand. On the other hand, such a mark of distinction, as St. George's Cross in Russia could be awarded only by order of the monarch, so the use of symbols of the cross of St. George unrelated with the monarchy may be perceived as "usurpation". It is important to note that in everyday situation the symbolic of Consulate assumes no other signs, besides national identity.

It is also important to note that among the emigrants, in general, there is no sense of the winners. At the event dedicated to the 65 th anniversary of the end of the Second World War, a new wave of migrants themselves proposed to change the format of the activities of Russian foreign representative offices to celebrate the end of the war without underlining of fact of Germany's defeat; in this case, it should be noted, that this initiative was accepted by all migrant groups. However, the symbols of this historic event are clear to all members of the new wave; they are perceived as positive and are used in commercial structures as well. For migrants of the "new wave" the following statement would be relevant: "The vast majority of our fellow citizens, regardless of gender, educational and professional belonging and type of community, continue to be proud of victory in the Great Patriotic War, the post-war reconstruction of the country, the great Russian culture, achievements of national space science and technology " $[9, \mathrm{p}$. 17]. In an interview with the representative of the "Russian Abroad" the question of the significance of the celebration of the 9th of May was met with a surprise and with a question: "Are we Soviet?" Which shows the relationship to this day, as to a "Soviet" holiday. Respondents recalled violent actions of the Soviet soldiers against some prisoners who found themselves in Germany. Since one of the first impressions of Russia is 
poverty and disorder, the military parades that are broadcast on television, are perceived by some respondents as an inappropriate waste of money. Among the migrants of "Russian Abroad" there is no clear perception of the term "Victory Day", especially because for many migrants of the first and second waves that day is associated with a forced repatriation and with memories of escaping from the Soviet Army. Among the first group of migrants the figure of Stalin is perceived definitely negatively, while for new wave representatives it is rather a matter of debate. At an official event of the Consulate one of the paragraphs in the program of activities was a "Portrait of Stalin". In the course of this event was played the song "Leningradskaya". It is quite clear that war veterans remembered "Leningrad", rather than "St. Petersburg", since most of their lives that city was called so. If migrants of "Russian Abroad" are characterized by a complete rejection of the Soviet system, for the "new wave" migrants political system of the USSR, the Soviet ideology in most cases remain outside of their active memories. In the memories of the USSR the main things are not about political persecution, party acts or social system, but about good memories of the people with whom the respondents contacted. There is also the fact that the Soviet everyday culture of late socialism can be attributed to the cultures of "low uncertainty avoidance." In these circumstances, the respondents passed their public establishment. Therefore, they highlight high stability and predictability of the Soviet society of that era, in contrast to the Soviet society at the time of Perestroika or the modern one. It is exactly the lack of uncertainty in terms of the late USSR and horizontal (stable) interpersonal relationships are considered by respondents as a value. [14] At the celebration of the Independence Day of Russia in the Russian Consulate it was organized a ceremonial reception, which was attended by migrants of "Russian Abroad" as well. At the same time interest to this holiday was generally higher than to the other public holidays. This circumstance is probably related to the fact that this holiday symbolizes the end of the Soviet era. So, it was interesting to note that the Russian Consulate reception on the $8^{\text {th }}$ of May 2012 was attended only by representatives of the Russian Orthodox Church of the Moscow Patriarchate and no representatives of the Russian Orthodox Church Outside of Russia, while at the reception in honour to Independence Day of Russia on June 12nd were more representatives of ROCOR than representatives of the ROC MP. This observed relation, however, may be a consequence of the fact that the $9^{\text {th }}$ of May fell on eve of the holiday of Mid-Easter and the ROCOR did not have any free from the liturgical duties priest being able to attend the event at the consulate.

\section{§ 4 Conclusion}

One of the most important aspects of cultural identity is a "cultural memory". Jan Assmann defines "cultural memory" as a common for each society and era special stability of the repeated use of texts, images, and customs, maintaining of which they (the societies) stabilize their own image and transmit collectively divided knowledge preferably (but not exclusively) of the past, and this knowledge encourages the consciousness of the unity and the features of the group. Communication features, such as rituals, songs, historical references, etc. give shape and semantic stem, and thereby they substantially define the cultural memory of a group or society. Analysis of the structure of the Russian-speaking scattering in Germany shows the presence of at least two non-equal intersecting cultural groups. To overcome the conflict and tension between the communities, an objective and accurate knowledge of value (cultural) systems of the relevant communities is very important, as well as qualitative and quantitative correlation between 
such systems. The problem is compounded by the fact that both groups call themselves Russian and are perceived by indigenous people and representatives of the country of origin as Russians, however it is a question about the various manifestations of cultural identity and cultural memory [50], non-distinguishing of which can affect the achievement of results of policies. Basis of differences between the two migrant communities is the distinguishing of identity and purpose of their residence outside of the country of origin. If the basic identity of Russian world is the idea that the period of the Soviet regime is the period of destruction of Russian culture, for the "late" migrants, ideas and symbols of the Soviet period are often parts of their identity [16]. Accordingly, the interpretation of historical events will be most likely an area of disagreement. Common holiday promotes cultural practices and standardized behaviour, but under conditions of existence of migrants with different interpretations of historical events it is difficult to talk about the presence of general holidays. Noteworthy is the fact that government representatives rather mark out the second group holidays. As, for example, observed consular initiative of the organization of holidays and other activities shows, the object of attention are migrants of the "new wave", while migrants "Russian Abroad" are often repelled, for example, by underlining their belonging to the Soviet cultural system. It comes despite the fact that by the first group migrants until now is persisted the ambivalence to the public holidays. Significant marker of culture of "old emigration" is the same anti-Soviet sentiment. For the "new wave" idea and symbols of the Soviet period often constitute a part of the identity. Memories of the respondents about the USSR are mainly associated not with the political system of this country, but with the personal relationships of respondents, which may indicate a shift from ideological content to the formal celebration to maintain horizontal relations with a the lack of desire and resources of interpretation and reinterpretation. Accordingly, due to the focus-shift of consideration and peculiarity socialization, the interpretation of historical events is rather an area of disagreement. There is still an interest to the holidays, established after the collapse of the USSR. And knowing this feature the unifying holidays and rituals can be built. «Exactly rituals, not urgent and supervisory institutions, paradoxically, explain the essence of the social order, as well as its stability. Therein lies ... a special socializing effectiveness of the holidays. Secondly, "everyone gets totally involved", the relations of the group become closer, removing the problem of interpersonal and intergroup communication barriers ... “ [30, p.17]. An important role in both groups is played by the cultural values on the basis of which individuals identify themselves as members of a cultural group. Result of value regulation in this case is the self-reference of diaspora members to "Russian". As unifying factor may be mentioned some universal values, such as the absence of war. At the same time the symbolic regulation is important, it involves extensive use of significant symbols, perceived by individuals as important for them. An example of the use of symbols may be an action "St. George Ribbon", which, despite the presence of the general historical grounds, has not become a common symbol. It is noteworthy that along with such bands ribbon-tricolors in colors of the Russian flag got more popular. Differences are observed in comprehension of the different waves of general symbolic experience, perception of socio-cultural community. For the latest wave of migrants it is more characteristic to have attention to the actual information, the desire to be in the same information flow that their compatriots. It is now possible to observe a tendency to the "cultural forgetting" and fragmentation of cultural memory in the "new 
wave" group, in the future one can predict decrease of impact of cultural memory to the formation of new identities and the growing importance of current cultural reality both receiving countries and Russia for new identities [25]. It is followed by the assumption that the hybrid identity with the trend toward greater influence in its elements of actual reality of the country of settlement will dominate in the nearest future in these groups. Immigrants from Russia are an important resource "soft power", which helps in particular to improve the image of Russia. For the West the image of Russia to had always the identification dichotomy: for the West Russia acted and acts as the main "other" in the dichotomy between the West-East, Europe and Asia, the civilizationbarbarism. Culture, spirituality and science of
Russian abroad had a great influence on debunking of the myths about Russia. And Russia got a real opportunity to overcome this dichotomy through a meeting of the West with native culture bearers. However, the principle of this resource is not yet completely understood, so it is very important to develop a migration study. Without reliable information about features of the scattering, all spent organizational and financial resources may not bring any desired result. A feature of the organization of immigrants in Germany can be used as an illustration of this. Lack of knowledge about the migrant's structure can lead to the fact that the applied measures (symbols, ideas, principles, etc.) would be incomprehensible or even would repel some resources, forcing them to work against the achievement of objectives.

\section{References}

Akhiezer A. (2004) Emigratsiia kak indikator sostoianiia rossiiskogo obshchestva [Emigration as an indicator of the state of Russian society]. «Russkii Arkhipelag» ["Russian Archipelago"]. available at: http://www.archipelag.ru/ru_mir/volni/hrono_retro/indication

Assmann J. (1988) Kollektives Gedächtnis und kulturelle Identität. [Collective Memory and Cultural Identity] In: Assmann J., Hцlscher T. (Ed.). Kultur und Gedächtnis [Culture and memory] Frankfurt am Main: Suhrkamp, pp. 9-19

Assmann J. (1992) Das kulturelle Gedächtnis. Schrift, Erinnerung und politische Identität in frühen Hochkulturen. [Cultural memory. Scripture, memories and political identity in ancient civilizations] München: Beck, p. 344

Dashkov S. MID dovolen. Podvedeny itogi raboty s sootechestvennikami v 2008 godu. [Foreign office is satisfied. The results of the work with compatriots in 2008].// Rossiiskaia gazeta [Russian newspaper] No 4820, 25.12.2008, p. 4

Denikin A.I. Ocherki russkoi smuty. V $3 \mathrm{kn}$. [Sketches of Russian turmoil. In 3 volumes], Vol. 1. Krushenie vlasti $i$ armii (fevral'-sentiabr' 1917) [The authorities and the army crash (FebruarySeptember 1917)], Moscow, 2005, p. 520

Doklad Ministerstva inostrannykh del Rossiiskoi Federatsii «Russkii iazyk v mire» [Report of the Ministry of Foreign Affairs of the Russian Federation "The Russian language in the world"], Moscow, 2003. available at: http://www.ln.mid.ru/ns-dgpch.nsf/0/432569ee00522d3c43256df9003b051c?Open Document

Federal'naya programma “Sootechestvenniki”. Programmasodeystviiadobrovol'nomupereseleniiu sootechestvennikov v Rossiiu" [Federal Program "Compatriots". Program to assist the voluntary resettlement of compatriots in Russia]. Federal'naya Migratsionnaya Sluzhba [Federal Migration Service] available at: http://www.fms.gov.ru/programs/fmsuds/ (data obrashcheniya: 20.03.2011) 
Federal'nyi zakon Rossiiskoi Federatsii ot 25 iiulia 2009 g. N 214-FZ «O vnesenii izmenenii v Federal'nyi zakon "O gosudarstvennoi politike Rossiiskoi Federatsii v otnoshenii sootechestvennikov za rubezhom» [Federal Law of 25 July 2009 N 214-FZ “On Amending the Federal Law” On State Policy of the Russian Federation on compatriots abroad"] Adopted by the State Duma on July 17, 2009. Federation Council approved July 18, 2009, available at: http://www.rg.ru/printable/2009/07/28/politdok.html

Gorshkov M.K., Tikhonova N.E. (2005) Rossiiskaia identichnost' v usloviiakh transformatsii: opyt sotsiologicheskogo analiza [Russian identity in transformation: the experience of sociological analysis]. Moscow: Nauka, p. 396

Gosudarstvennaia programma Rossiiskoi Federatsii. «Razvitie vneshneekonomicheskoi deiatel'nosti» [State Program of the Russian Federation. "The development of foreign economic activity"] by the Ministry of Economic Development of the Russian Federation. available at: http:/ www.economy.gov.ru/minec/about/structure/depsvod/doc20120905_02\#

Hettlage R. (1993) Diaspora: Umrisse einer soziologischen Theorie. [Diaspora: outline of a sociological theory] In: Mihran Dabag / Kristin Platt (Ed.)., Identität in der Fremde. [Identity in a Foreign Land] Bochum, pp. 75-105.

Karasin G.B. (2007) Rossiia i sootechestvenniki [Russia and its compatriots]. Mezhdunarodnaia zhizn' [International Affairs]. No 12, 2007, pp. C.12-23

Kontseptsiia vneshnei politiki Rossiiskoi Federatsii. [Foreign Policy Concept of the Russian Federation] Approved July 12, 2008 № Pr-1440. Rossiiskaia gazeta. [Russian newspaper] on July 12,2008

Lahusen T., Kuperman G. (1993) Late Soviet Culture From Perestroika to Novostroika. Durhan: N.C. Duke University Press, p.171

Malakhov V.S. (2010) Immigratsionnye rezhimy v gosudarstvakh Zapada $i$ v Rossii: teoretikopoliticheskii aspekt. Chast' 2 [Immigration regimes in the countries of the West and in Russia: theoretical and political aspect. Part 2] Polis, No 4, 2010, pp. 150-158

Natsional'no-grazhdanskie identichnosti $i$ tolerantnost'. Opyt Rossii $i$ Ukrainy $v$ period transformatsii [The national civil identity and tolerance. Experience of Russia and Ukraine in the transformation period], Drobizheva L.M., Golovakha E.I. (Ed.). Kiev, 2007, p. 280

Neklessa A. (2001) Novaia kartografiia mira [The new mapping of the world] Ekonomicheskie strategii [Economic Strategies], No 1, 2001, pp. 32-41

Polian P.M (2005) Emigratsiia: kto i kogda v XX veke pokidal Rossiiu [Emigration: who and where in the XX century left Russia]. In: Rossiia i ee regiony $v$ XX veke: territoriia-rasselenie - migratsii [Russia and its regions in the XX century: the territory - resettlement - migration] Ed. Glezer O, Polian P., Moscow, OGI, pp. 493-519

Polian P.M. (2002) Zhertvy dvukh diktatur: zhizn', trud, unizhenie i smert' sovetskikh voennoplennykh i ostarbaiterov na chuzhbine i na rodine [Victims of Two Dictatorships: life, work, humiliation and death of Soviet prisoners of war and ostarbeiters in exile and at home], Moscow, ROSSPEN, 2002, p.894

Pomozova N.B. (2012) Sravnitel'nyi analiz strategii formirovaniia grazhdanskoi identichnosti v Rossii i Kitae. [Comparative analysis of the strategies to achieve the civic identity in Russia and China]. Vestnik MGIMO-Universiteta [Bulletin of the MGIMO-University], No 4(25), 2012, pp. 210-215 
Ponomareva A.M., Tatunts S.A. (2010) Immigratsiia, kak problema bezopasnosti RF. [Immigration as a security problem of the Russian Federation.]. Polis, No 4, 2010, pp. 135-150

Popkov V.D. (2006) Osnovy «russkogo mira»: vektory formirovaniia edinogo prostranstva sootechestvennikov [Fundamentals of the "Russian world": the formation of a common space of compatriots]. Fond «Russkii mir» [Foundation "Russian world”], available at: http://www.russkiymir. ru/analytics/tables/news/119894/

Popkov V.D. (2007) Emigratsiia iz Rossiiskoi imperii Sovetskogo Soiuza v Evropu: sravnitel'nyi analiz. [Emigration from the Russian Empire and the Soviet Union in Europe: a comparative analysis]. Zhurnal sotsiologii i sotsial'noi antropologii [Journal of Sociology and Social Anthropology], T. 10, No. 3, 2007, pp. 143-159

Popkov V.D. (2011) Russkoiazychnye prostranstva za rubezhom: spetsifika formirovaniia $i$ osnovnye osobennosti [Russian-speaking space abroad: specificity of formation and the main features]. Vestnik Instituta Kennana v Rossii [Herald Kennan Institute in Russia], No. 19, 2011, pp. 45-57

Popkov V.D. (2013) Kul'turnaia pamiat' russkoiazychnykh migrantov v Germanii: vliianie na formirovanie novykh identichnostei vykhodtsev iz byvshego SSSR [Cultural memory of Russianspeaking migrants in Germany: influence on the formation of new identities of immigrants from the former Soviet Union]. Zhurnal sotsiologii i sotsial'noi antropologii. [Journal of Sociology and Social Anthropology] T. 16, No. 1 (66), 2013, pp. 148-166

Pushkareva N.L. (1966) Vozniknovenie i formirovanie rossiiskoi diaspory za rubezhom. [The origin and formation of the Russian diaspora abroad]. Educational Orthodox Society «Russia in colours» available at: http://ricolor.org/history/re/24/

Robinson P. (2010) The White Russian Army in exile. Oxford: Clarendon Press, p. 257

Saraikina D.I. (2011) Politicheskii prazdnik kak mekhanizm interpretatsii politicheskoi real'nosti [Political feast as a mechanism for the interpretation of political reality]. Vestnik Tomskogo gosudarstvennogo universiteta. Seriia «Filosofiia. Sotsiologiia. Politologiia» [Bulletin of Tomsk State University. Series “Philosophy. Sociology. Politics»], No. 3(15), 2011, pp. 145-149

Schmale W. (1998) Historische Komparatistik und Kulturtransfer. Europageschichtliche Perspektiven für die Landesgeschichte. Eine Einführung unter besonderer Berücksichtigung der Sächsischen Landesgeschichte. [Historical comparative literature and cultural transfer. European Historical perspectives on the country's history. An introduction with special consideration of the Saxon State story] In: Herausforderungen. Historisch-politische Analyse [Challenges. Historical and Political Analysis] Bd. 6. Bochum: Winkler, pp. 109-111

Shcherbinin A.I. (2007) Kommunikativnaia priroda politicheskogo prazdnika [Communicative nature of political feast]. In: Politicheskii marketing [Political Marketing], No. 6, 2007, pp. 5-20

Shtompka P. (2001) Kul'turnaia travma v postkommunisticheskom obshchestve [Cultural trauma in post-communist society]. Sotsiologicheskie issledovaniia. [Sociological studies] No 2, 2001, pp. 3-12

Sokolov M. (1999) Chetyre volny. [Four waves]. «Russkii Arkhipelag» ["Russian Archipelago"]. available at: http://www.archipelag.ru/ru_mir/volni/hrono_retro/4wave/

Tarle G. (1994) Istoriia rossiiskogo zarubezh'ia: terminy; printsipy periodizatsii. [History of the Russia abroad: terms, principles of periodization]. In: Kul'turnoye naslediye rossiyskoy emigratsii: 1917-1940. [Cultural Heritage of the Russian emigration: 1917-1940]. Ed. Chelisheva E.P., Shakhovsky D.M. Book 1, Moscow, Naslediye, pp 16-24 
Tishkov V.A. (2001) Gde i kogda rossiiskaia diaspora? [Where and when the Russian diaspora?] In: Natsional'nyye diaspory $v$ Rossii i za rubezhom $v$ XIX-XX $v$. [National diaspora in Russia and abroad in XIX-XX centuries]. Ed. Polyakova Y.A., Tarle G.Y., Moscow: IRI RAN, 2001, pp. 27-35.

Vishnevskii A., Zaionchkovskaia Zh. (1992) Volny migratsii: Novaia situatsiia [Waves of migration: The new situation] In: Svobodnaia mysl' [Free Thought] , No 12, pp. 4-16

Vorausberechnung der Bevölkerung mit Migrationshintergrund in Bayern bis 2020 [Precalculation of the population with a migration background in Bavaria 2020] Statistisches Amt der Landeshauptstadt München [Statistical Office of Munich] available at: http://www.statistik.bayern.de/medien/statistik/ demwa/biz_sonderdruck_migrationshintergrund.pdf

Zaionchkovskaia Zh.A. (2004) Emigratsiia $v$ dal'nee zarubezh'e [Emigration to the foreign countries]. «Russkii Arkhipelag» ["Russian Archipelago"]. available at: http://www.archipelag.ru/ ru_mir/volni/4volna/out-migration/

Zaionchkovskaia Zh.A. (2005) Chetvertaia volna: Migratsionnyi obmen Rossii so stranami dal'nego zarubezh'ia. Nesostoiavshiisia «deviatyi val» [Fourth Wave: The migration exchange between Russia and the CIS countries. Missed "The Ninth Wave."]. In: Rossiia i ee regiony v XX veke: territoriia - rasselenie - migratsii [Russia and its regions in the XX century: the territory resettlement - migration]. Ed. Glezer O. and Polian P., Moscow, OIG, pp. 545-551

Zemskov V.N. (2004) Repatriatsiia peremeshchennykh sovetskikh grazhdan [Repatriation of displaced Soviet citizens]. «Skepsis», available at: http://scepsis.net/library/id_1234.html

\title{
Взаимодействие Российского государства с эмигрантскими сообществами
}

\author{
В.А. Базанов \\ Мюнхенский университет Людвига-Максимилиана \\ Германия, 80539, Мюнхен, Гешвистер-Шолль-Плаи 1
}

\begin{abstract}
В статье на основе материалов качественного соииологического исследования проводится анализ формирования и сопоставление установок выделенных групп мигрантов по отнотению $\kappa$ государству, к государственным праздникам.

На основе анализа проведенных 75 тематически структурированных интервью автор сравнивает особенности переселения двух групп, их поведение, отношение к органам власти. Основой различия двух эмигрантских сообществ служит различия в идентичности и иели их пребывания вне страны происхождения. Представители «русского зарубежья» длительное время дистаниировались от государства, которое располагалось на территории исхода, что не в такой степени характерно для представителей «новой волныl». При этом само государство как таковое не воспринимается враждебно. Настороженное отнотение к государству мигрантов «новой волны» часто переносится на государство приема. Заметны различия в символической регуляции праздников. Интерпретация исторических событий является скорее областью разногласий. Примером использования символов может служить акиия «георгиевская ленточка», которая, несмотря на присутствие общего исторического основания, не стала общим символом.
\end{abstract}


Переселенцы из нашей страны являются важным ресурсом «мягкой силы», помогающей улучшению имиджа России. Выделение особенностей культуры и восприятия символов каждой группы может повысить эффективность работы с соотечественниками за рубежом.

Ключевые слова: мигранты, культурное пространство, символ, праздник, «русский мир», «мягкая сила».

Научная специальность: 22.00.00 - соџиологические науки. 